\title{
Multilayered Sn-Zn/Zn/Cu Alloy Film Electrode Prepared by Electroplating Method for Lithium Secondary Batteries
}

\author{
Shingo KITAMURA, ${ }^{\text {* }}$ Lianbang WANG, ${ }^{\text {b Shigeo TANASE, }}{ }^{\mathrm{b}}$ \\ Keigo OBATA, ${ }^{\mathrm{a}}$ and Tetsuo SAKAI ${ }^{\mathrm{b}}$
}

\begin{abstract}
${ }^{a}$ R \& D Center, Daiwa Fine Chemicals Co., Ltd. (21-8, Minamifutami, Futami-cho, Akashi, Hyogo 674-0093, Japan)
${ }^{b}$ National Institute of Advanced Industrial Science and Technology, Kansai Center (1-8-31, Midorigaoka, Ikeda, Osaka 563-8577, Japan)
\end{abstract}

Received May 29, 2003 ; Accepted October 8, 2003

\begin{abstract}
A multilayered $\mathrm{Sn}-\mathrm{Zn} / \mathrm{Zn} / \mathrm{Cu}$ film electrode was prepared by an electroplating method and the electrode performance was investigated. The heat-treated electrode showed an excellent charge-discharge performance; a discharge capacity of around $300 \mathrm{mAh} \mathrm{g}^{-1}$ was maintained even after 100 cycles. The electrode was mainly composed of a Cu6 $\mathrm{Sn}_{5}$ phase due to interdiffusion of $\mathrm{Sn}$ and $\mathrm{Cu}$ during heat-treatment process. At the same time, two $\mathrm{Zn}$ enriched layers were formed. This optimized electrode structure would relax volume expansion and phase transition during cycling, resulting in an enhanced electrode performance.
\end{abstract}

Key Words : Sn-based Alloy Electrode, Electroplating Method, Multilayer Film

\section{Introduction}

Sn-based alloys have been studied as negative electrode materials for lithium secondary batteries. Although they have larger theoretical capacity than that of graphite. they generally don't have an enough cyclic life to be used as commercial products. One of the serious problems is that large volume expansion and structure transition in the electrode occurs during charge-discharge process, which cause cracks, at last, resulting in a capacity decay. Many attempts have been made for the purpose of practical applications by forming various Snbased alloys/intermetallic compounds and composites with inorganic and organic agents. ${ }^{1-7)}$

An electroplating method has been used to prepare Snbased alloy electrodes. ${ }^{1,8-10)}$ In this preparing process, any binder and conducting agents are not needed, and therefore a compact electrode with low cost could be prepared. In our previous work, $\mathrm{Sn}$ and $\mathrm{Sn}-\mathrm{Zn}$ films on a $\mathrm{Cu}$ foil ( $\mathrm{Sn} / \mathrm{Cu}$ and $\mathrm{Sn}-\mathrm{Zn} / \mathrm{Cu}$ electrodes) have been developed using the electroplating method, and its performance has been reported. ${ }^{9}{ }^{10)}$ It was found that these electrodes with heat-treatment at appropriate conditions showed a high electrochemical capacity and a good cycle life because of the formation of $\mathrm{Cu}_{6} \mathrm{Snn}_{5}$ due to interdiffusion of $\mathrm{Sn}$ in the plated film and $\mathrm{Cu}$ from the $\mathrm{Cu}$ foil. In this work, a multilayered $\mathrm{Sn}-\mathrm{Zn} / \mathrm{Zn} / \mathrm{Cu}$ film electrode has been prepared using the electroplating method. We expect that a $\mathrm{Zn}$ layer would strengthen an adhesion between an active material and a $\mathrm{Cu}$ foil, resulting in a better cyclic performance than that of the $\mathrm{Sn}-\mathrm{Zn} / \mathrm{Cu}$ electrode. The structure and performance of the multilayered $\mathrm{Sn}-\mathrm{Zn} / \mathrm{Zn} / \mathrm{Cu}$ electrode have been investigated in detail.

\section{Experimental}

A $\mathrm{Zn}$ film was electroplated on a $\mathrm{Cu}$ foil (current col- lector), and then a Sn-Zn alloy film was electroplated on the top of that to produce a multilayered $\mathrm{Sn}-\mathrm{Zn} / \mathrm{Zn} / \mathrm{Cu}$ film electrode. A $\mathrm{Zn}$ plating solution was composed of $0.16 \mathrm{M}\left(=\mathrm{mol} \mathrm{dm}{ }^{-3}\right) \mathrm{Zn}^{2+}$ and $0.65 \mathrm{M}$ Sulfosuccinic acid, and $\mathrm{pH}$ was adjusted to $2-5$. In the case of a $\mathrm{Sn}-\mathrm{Zn}$ alloy plating, a solution composition was $0.18 \mathrm{M} \mathrm{Sn}^{2+}, 0.04 \mathrm{M}$ $\mathrm{Zn}^{2+}$, and 0.5 M Sulfosuccinic acid, and $\mathrm{pH}$ was adjusted $3-6$. The current density of the $\mathrm{Zn}$ and Sn-Zn alloy plating was $10-50 \mathrm{~mA} \mathrm{~cm}^{-2}$ and $5-20 \mathrm{~mA} \mathrm{~cm}{ }^{-2}$, respectively. The content of $\mathrm{Zn}$ in the $\mathrm{Sn}-\mathrm{Zn}$ film was around $10 \mathrm{wt} \%$. The thickness of the plated $\mathrm{Zn}$ and $\mathrm{Sn}-\mathrm{Zn}$ films was around 0.5 and $5 \mu \mathrm{m}$, respectively. In order to improve the performance of the electrode, heat-treatment has been carried out at $200^{\circ} \mathrm{C}$ for 17 hours under vacuum.

Electrode structures were characterized by X-ray diffraction analysis (XRD) using a M06XCE diffractometer with $\mathrm{Cu}$ radiation source (MAC science), scanning electron microscopy (SEM) (HITACHI, S-2150) and energy dispersion X-ray spectroscopy (EDX) (HORIBA, EMAX7000).

Charge-discharge tests were conducted using a screw type stainless cell composed of the multilayered $\mathrm{Sn}-\mathrm{Zn}$ / $\mathrm{Zn} / \mathrm{Cu}$ film electrode as working electrode $(\phi 11)$, a $\mathrm{Li}$ metal sheet as counter electrode $(\phi 18)$ and a separator. Electrolyte was $1 \mathrm{M} \mathrm{LiPF}_{6}$ in EC and DMC (1:2 by volume). All cells were assembled in an argon atmosphere globe box. Cyclic tests were carried out at constant current density; the current density was $0.2 \mathrm{~mA} \mathrm{~cm}^{-2}$ for $1^{\text {st }}$ charging (Li insertion) and $0.2 \mathrm{~mA} \mathrm{~cm}{ }^{-2}$ for $1^{\text {st }}$ discharging ( $\mathrm{Li}$ extraction), and was $0.4 \mathrm{~mA} \mathrm{~cm} \mathrm{~cm}^{-2}$ for charging and $1.0 \mathrm{~mA} \mathrm{~cm}{ }^{-2}$ for discharging after following cycles. The potential range was $0-1.0 \mathrm{~V}$ vs. $\mathrm{Li} / \mathrm{Li}^{+}$.

\section{Results and Discussion}

Figure 1 shows the first cycle profiles of the as-plated 
and heat-treated multilayered $\mathrm{Sn}-\mathrm{Zn} / \mathrm{Zn} / \mathrm{Cu}$ film electrodes. It can be seen that these curves were very different; there was an obvious plateau about $0.4 \mathrm{~V}$ vs. $\mathrm{Li} / \mathrm{Li}^{+}$ on charging process and several plateaus on discharging process for the as-plated electrode. On contrast, a plateau at about $0.2 \mathrm{~V}$ was present on charging process and a smooth curve was observed on discharging process for the heat-treated electrode. It was suggested that a main component of the as-plated electrode was different from that of the heat-treated one.

Figure 2 presents the cyclic behaviors of the as-plated and heat-treated electrodes. An initial capacity of the asplated electrode was very high, but the cycleability was poor. A discharge capacity of the as-plated electrode was high around $700 \mathrm{mAh} \mathrm{g}^{-1}$ within first 10 cycles. During the following 10 cycles, the discharge capacity drastically


treated electrode showed an excellent cyclic performance though the capacity fade for intial several cycles was significant. A discharge capacity of about $300 \mathrm{mAh} \mathrm{g}^{-1}$ was maintained even after 100 cycles.

In order to investigate the effect of these electrode structures on the performances of these electrodes, the structure difference between the as-plated and heattreated electrode was investigated. Figure 3 presents the XRD patterns of the as-plated and heat-treated electrodes. Peaks attributed to $\mathrm{Sn}$ and $\mathrm{Cu}$ (foil) were observed for the as-plated electrode, but there was no peak for $\mathrm{Zn}$ due

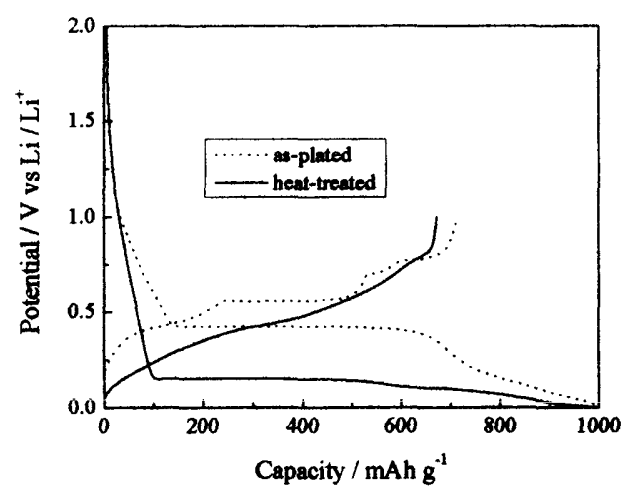

Fig. 1 First charge-discharge curves of the as-plated and heat-treated multilayer $\mathrm{Sn}-\mathrm{Zn} / \mathrm{Zn} / \mathrm{Cu}$ film electrodes.



Fig. 2 Cyclic behaviors of as-plated and heat-treated multilayer $\mathrm{Sn}-\mathrm{Zn} / \mathrm{Zn} / \mathrm{Cu}$ film electrodes. to lower $\mathrm{Zn}$ content. In the case of the heat-treated electrode, it was found that a $\mathrm{Sn}$ phase decreased, and $\mathrm{Cu}_{6} \mathrm{Sn}_{5}$ intermetallic compound was formed and became a main component because of interdiffusion of $\mathrm{Sn}$ and $\mathrm{Cu}$ during heat-treatment process.

Figure 4 shows distributions of $\mathrm{Sn}, \mathrm{Cu}$ and $\mathrm{Zn}$ elements on cross-section of the as-plated and heat-treated electrodes. For the as-plated electrode, the electroplated $\mathrm{Zn}$ film was observed clearly between the plated $\mathrm{Sn}-\mathrm{Zn}$ film and the $\mathrm{Cu}$ foil. The result also shows that the content of $\mathrm{Zn}$ in the plated Sn-Zn film is low, so it cannot be observed by XRD analysis. In the case of the heat-treated electrode, the figure shows the trend that $\mathrm{Cu}$ diffused from $\mathrm{Cu}$ foil toward the plated film, resulting in the formation of $\mathrm{Cu}_{6} \mathrm{Sn}_{5}$ during heat-treatment. On the other hand, $\mathrm{Zn}$ between the plated $\mathrm{Sn}-\mathrm{Zn}$ film and $\mathrm{Cu}$ foil separated into two parts; one was a center of the $\mathrm{Cu}_{6} \mathrm{Sn}_{5}$ layer and the other was a interface between the $\mathrm{Cu}_{6} \mathrm{Sn}_{5}$ layer and $\mathrm{Cu}$ foil. As a result, a multilayered structure electrode composed of $\mathrm{Cu}_{6} \mathrm{Sn}_{5}$ and $\mathrm{Zn}$ enriched layers was formed by heat-treating an as-plated $\mathrm{Sn}-\mathrm{Zn} / \mathrm{Zn} / \mathrm{Cu}$ film electrode, as shown in Fig. 5.

Based on the relations between the electrode structures and charge-discharge curves or cyclic behaviors of the as-plated and heat-treated electrodes, the formation of $\mathrm{Cu}_{6} \mathrm{Sn}_{5}$ layer could contribute to a good performance

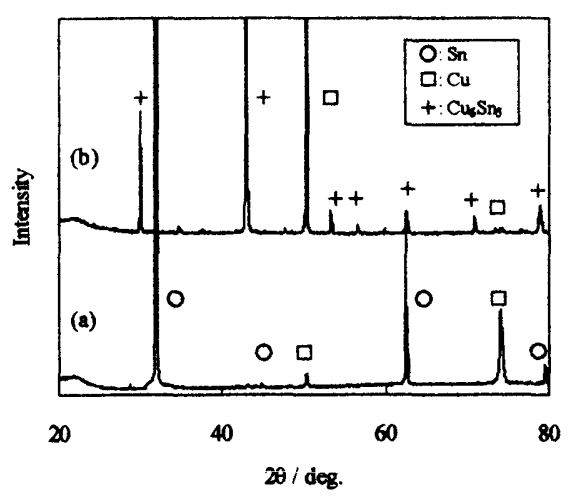

Fig. $3 \mathrm{XRD}$ patterns of as-plated (a) and heat-treated (b) multilayer $\mathrm{Sn}-\mathrm{Zn} / \mathrm{Zn} / \mathrm{Cu}$ film electrodes.

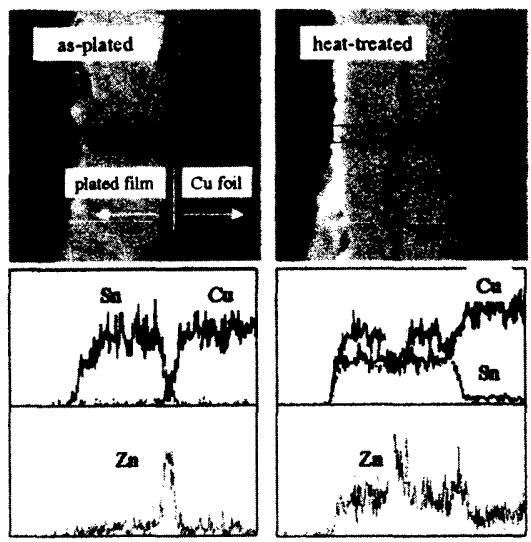

Fig. 4 Distributions of $\mathrm{Sn}, \mathrm{Cu}$, and $\mathrm{Zn}$ elements on crosssection of as-plated and heat-treated multilayer $\mathrm{Sn}-\mathrm{Zn} / \mathrm{Zn} / \mathrm{Cu}$ film electrodes. 




Fig. 5 Electrode structure model of multilayer $\mathrm{Sn}-\mathrm{Zn} / \mathrm{Zn} / \mathrm{Cu}$ film electrode heat-treated at $200^{\circ} \mathrm{C}$ for 17 hours.

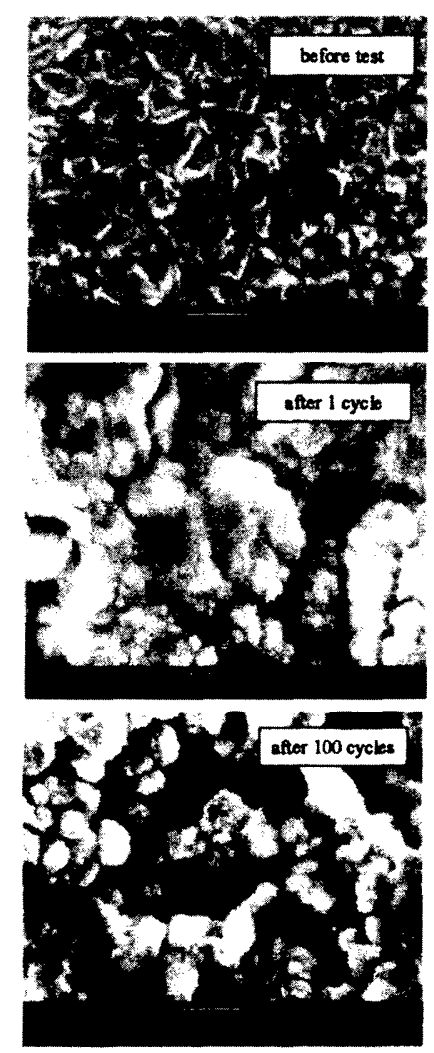

Fig. 6 Surface morphology of heat-treated electrodes before cyclic test and after 1 cycle and after 100 cycles.

of the heat-treated electrode. It was suggested that during the charge process of the heat-treated electrode, $\mathrm{Li}$ reacted with $\mathrm{Cu}_{6} \mathrm{Sn}_{5}$ to yield a $\mathrm{Li}_{2} \mathrm{CuSn}$-type phase firstly, and further lithiation of $\mathrm{Li}_{2} \mathrm{CuSn}$ proceeded to yield $\mathrm{Li}_{4.4} \mathrm{Sn}$ and extracted $\mathrm{Cu}^{\left.2{ }^{2}{ }^{4}\right)}$ At the same time, extracted $\mathrm{Cu}$ was used as a binder and matrix in the electrode, which would relax volume expansion of the electrode during charge-discharge process. ${ }^{2}$ On the other hand, the $\mathrm{Zn}$ enriched layer sandwiched betwecn two $\mathrm{Cu}_{0} \mathrm{Sn}_{3}$ layer could also relax volume expansion and the other $\mathrm{Zn}$ enriched layer at interface between $\mathrm{Cu}_{6} \mathrm{Sn}_{5}$ layer and $\mathrm{Cu}$ foil would strengthen an adhesion of the interface. So the good performance of the heat-treated electrode was obtained by forming the optimized multilayer structure, composed of $\mathrm{Cu}_{6} \mathrm{Sn}_{5}$ intermetallic and $\mathrm{Zn}$ enriched layers.
The surface morphology of the heat-treated electrode before and after charge-discharge cycles have been shown in Fig. 6. The surface of the electrode before test looks like wrinkle but evenly. After 1st cycle, it was observed that the surface morphology has been changed drastically and cracks emerged. As charge-discharge cycle proceeded further, for example after 100 cycles, the active material broke to fine particles. It suggests the capacity decay of the electrode can be attributed to the loss of the contact between the active material particles, and the adhesion between the active material layer and the $\mathrm{Cu}$ foil due to the formation of cracks, resulted from the volume expansion and phase transition during chargedischarge process. In order to use Sn-based alloys in $\mathrm{Li}$ secondary batteries, this problem should be solved.

\section{Conclusion}

In this work, we prepared the multilayered $\mathrm{Sn}-\mathrm{Zn} / \mathrm{Zn} /$ $\mathrm{Cu}$ film electrode by the electroplating method and its performance as negative electrode for lithium secondary batteries has been investigated. Experimental results showed that the heat-treated electrode was composed of $\mathrm{Cu}_{6} \mathrm{Sn}_{5}$ and $\mathrm{Zn}$ enriched layers, and showed an excellent cyclic performance; a discharge capacity of about 300 $\mathrm{mAh} \mathrm{g}^{-1}$ was maintained even after 100 cycles. The multilayered $\mathrm{Sn}-\mathrm{Zn} / \mathrm{Zn} / \mathrm{Cu}$ film electrode would be a promising negative electrode material for lithium secondary batteries.

\section{Acknowledgement}

This work is a part of "Regional Consortium Research Development Work" supported by METI.

\section{References}

1) Y. Yang, M. Winter, and J. O. Besenhard, Solid State Ionics, 90, 281 (1996).

2) K. D. Kepler, J. T. Vaughey, and M. M. Thackeray, J. Power Sources, 81-82, 383 (1999).

3) O. Mao, R. A. Dunlap, and J. R. Dahn, J. Electrochem. Soc., 146, 405 (1999).

4) D. Larcher, L. Y. Beaulieu, D. D. MacNeil, and J. R. Dahn, J. Electrochem. Soc., 147, 1658 (2000).

5) H. Sakaguchi, H. Maeta, M. Kubota, H. Honda, and T. Esaka, Electrochemistry, 68, 632 (2000).

6) X. W. Zhang, C. Wang, A. j. Appleby, and F. E. Little, J. Power Sources, 109, 136 (2002).

7) H. Y. Lee, S. W. Jang, S. M. Lee, S. J. Lee, and H. K. Baik, J. Power Sources, 112, 8 (2002).

8) N. Tamura, R. Ohshita, M. Fujimoto, S. Fujitani, M. Kamino, and I. Yonezu, J. Power Sources, 107, 48 (2002).

9) S. Kitamura, D. H. Kim, M. Yoshimoto, K. Obata, T. Sonoda, and T. Sakai, Proceedings of the 42nd Battery Symposium in Japan, p.288 (2001).

10) L. Wang, S. Kitamura, T. Sonoda, D. H. Kim, K. Obata, S. Tanase, and T. Sakai, Proceedings of the 43rd Battery Symposium in Japan, p.25 (2002). 